where they suggest laminectomy as the procedure of choice, but neither mentions simultaneous anterior and posterior involvement. Adendorff et al (1987) reported two patients with circumferential spinal disease out of 703 with tuberculous spines; in one the posterior destruction was unrecognised and the patient, like ours, became paraplegic after anterior decompression.

With circumferential spinal involvement there is severe spinal instability analogous to an unstable fracturedislocation; either anterior or posterior decompression will merely contribute to further instability. Restoration of stability is a priority, but most anterior fixation devices depend on intact posterior vertebral elements and are inappropriate. Posterior spinal instrumentation can achieve immediate stability. There is also less likelihood of intra-operative spinal displacement with the patient prone than in the lateral decubitus position.

The spine should be exposed with care, recognising the danger of dissecting on the carious laminae. A temporary unilateral stabilising Harrington distraction rod is inserted and an adequate laminectomy/debridement performed; then the spine is fused definitively. We prefer double Harrington distraction rods with sublaminar and longitudinal interspinous wiring (Figs 3 and 4).
The interspinous wire is applied before distracting the Harrington rods to prevent over-distraction and to assist spinal realignment. Pedicular fixation is avoided since it may obstruct subsequent insertion of an anterior strutgraft. If neurological recovery does not ensue within a few weeks an anterior decompression can then be performed safely in the knowledge that the spine is stable. If anterior destruction is extensive an anterior strut-graft should be inserted irrespective of whether anterior decompression is necessary.

The authors wish to express their thanks to Drs $\mathbf{M}$. Paterson and $\mathbf{P}$ Anderson for their help in the management of this patient, and to the Superintendent of Princess Alice Orthopaedic Hospital for permission to publish.

No benefits in any form have been received or will be received from a commercial party related directly or indirectly to the subject of this article.

\section{REFERENCES}

Adendorfi JJ, Boeke EJ, Lazarus C. Pott's paraplegia. S Afr Med J $1987 ; 71: 427-8$.

Babhulkar SS, Tayade WB, Babhulkar SK. Atypical spinal tuberculosis J Bone Joint Surg [ Br] 1984; 66-B:239-42.

Jacobs P. Osteo-articular tuberculosis in coloured immigrants: a radiological study. Clin Radiol 1964; 15:59-69.

Naim-Ur-Rahman. Atypical forms of spinal tuberculosis. $J$ Bone Joint Surg [Br] 1980; 62-B:162-5.

\title{
GIANT CELL TUMOURS OF THE PROXIMAL FIBULA
}

\author{
M. FAROOQUE, A. BIYANI, A. ADHIKARI
}

Giant cell tumours of the proximal fibula are relatively uncommon and their reported incidence in the fibular head varies from $3 \%$ to $8 \%$ (Goldenberg, Campbell and Bonfiglio 1970; McGrath 1972; Sung et al 1982; Campanacci et al 1987). Excision of the proximal fibula is the usual treatment, but the operative technique has not been precisely described and a study specifically dealing with fibular lesions is lacking. In this report we emphasise the importance of excising the entire proximal tibiofibular joint in preference to disarticulation.

Patients, methods and results. Between 1981 and 1987 we treated seven men and two women with giant cell tumours of the proximal fibula. Their mean age was 41 years

M. Farooque, MS, D Orth, Additional Professor

A. Biyani, MS, Senior Resident

A. Adhikari, MS, Junior Resident

Department of Orthopaedics, All India Institute of Medical Sciences,

Ansari Nagar, New Delhi 110029, India.

Correspondence to Dr M. Farooque.

(C) 1990 British Editorial Society of Bone and Joint Surgery $0301-620 X / 90 / 4 R 78 \$ 2.00$

J Bone Joint Surg [ Br] 1990; 72-B: 723-4. (range 34 to 52). Seven patients were treated for the primary lesions and two for recurrent tumours. In all cases the diagnosis was confirmed histologically.

In the patients with a primary tumour, this was excised extraperiosteally with a margin of healthy tissues, including 4 to $6 \mathrm{~cm}$ of normal bone distal to the lesion; proximally 3 to $5 \mathrm{~mm}$ of the subarticular portion of the lateral tibial condyle, together with the proximal tibiofbular joint (PTFJ) was excised with a curved osteotome. The postoperative course was uneventful and there were no complications. None of these cases had any recurrence after an average follow-up of 4.2 years (range 2 to 7 ).

Of the two patients treated for recurrence, one had had the tibiofibular joint disarticulated but developed a soft tissue recurrence two years after the operation. For this, a radical excision was performed; a segment of the peroneal nerve had to be sacrificed. Four years later she was clinically and radiographically free of recurrence, and had satisfactory function with a foot-drop splint.

The other patient with a recurrence also had a disarticulation of the proximal tibiofibular joint; he developed a soft tissue recurrence with extension into the 
lateral tibial condyle three years after his operation (Fig. 1). This tumour was widely excised with a margin of healthy tissue and again a segment of common peroneal nerve had to be excised as it was engulfed in the tumour mass. In addition, the entire lateral tibial condyle was resected and the tibial plateau was reconstructed using the articular surface of the patella, which was reinforced by a fibular strut graft and iliac autografts. Adequate stability was achieved by screw fixation. The limb was immobilised in a long leg plaster for three months followed by six weeks of non-weight-bearing followed by progressive weight-bearing. Five years later he had painless knee movement of $0^{\circ}$ to $100^{\circ}$ and was able to perform his normal activities independently using a footdrop shoe insert. There was no evidence of recurrence (Fig. 2).

Discussion. Goldenberg et al (1970) and Sung et al (1982) have reported a recurrence rate of $30 \%$ and $12 \%$ respectively of giant cell tumours of the proximal fibula. Although the number of cases in our series is small, our experience has led us to believe that instead of disarticulating the tibiofibular joint, proximal fibular lesions should be excised with a margin of contiguous tibial condyle. None of the seven cases treated in this way had any recurrence during the period of follow-up; the joint was, however, not excised in the two patients who subsequently presented with recurrence and they required further extensive operations. Excision of the joint ensures complete removal of the tumour mass while disarticulation leaves behind synovial tissue which may already have been infiltrated. Moreover, further soft tissue seeding may take place if the tumour tissue is entered during disarticulation.

Extension of the tumour to the adjacent tibia, as seen in one of our patients is rare and only one similar case has been previously reported (Tornberg, Dick and

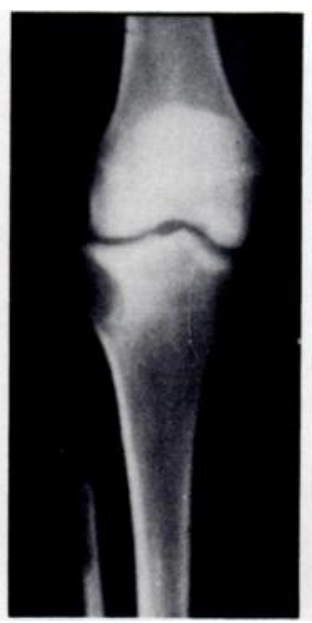

Fig. 1

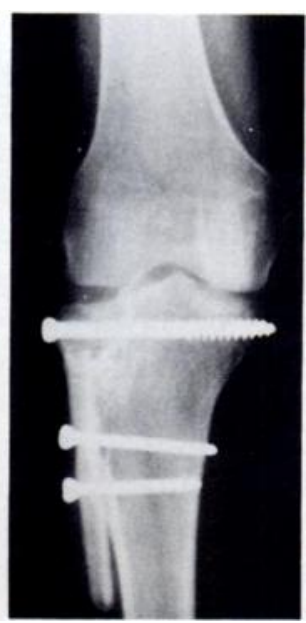

Fig. 2
Johnston 1975). Reconstruction of the tibial plateau in our case permitted restoration of useful knee function without any instability.

No benefits in any form have been received or will be received from a commercial party related directly or indirectly to the subject of this article.

\section{REFERENCES}

Campanacci M, Baldini N, Boriani S, Sudanese A. Giant-cell tumor of bone. J Bone Joint Surg [Am] 1987; 69-A :106-14.

Goldenberg RR, Campbell CJ, Bonfiglio M. Giant-cell tumor of bone: an analysis of two hundred and eighteen cases. J Bone Joint Surg [Am] 1970; 52-A :619-64.

McGrath PJ. Giant-cell tumour of bone: an analysis of fifty-two cases. J Bone Joint Surg [Br] 1972; 54-B :216-29.

Sung HW, Kuo DP, Shu WP, et al. Giant-cell tumor of bone: analysis of two hundred and eight cases in Chinese patients. J Bone Joint Surg [ Am] 1982; 64-A:755-61.

Tormberg DN, Dick HM, Johnston AD. Multicentric giant-cell tumors in the long bones: a case report. J Bone Joint Surg [Am] 1975; 57A :420-2. 